\title{
Mass Development of Diazotrophic Cyanobacteria (Nostocales) and Production of Neurotoxic Anatoxin-a in a Planktothrix (Oscillatoriales) Dominated Temperate Lake
}

\author{
Magdalena Toporowska • Barbara Pawlik- \\ Skowrońska $\cdot$ Renata Kalinowska
}

Received: 22 March 2016/Accepted: 28 July 2016/Published online: 10 August 2016

(C) The Author(s) 2016. This article is published with open access at Springerlink.com

\begin{abstract}
In spite of extensive studies on multispecies toxigenic cyanobacterial blooms, they are still difficult to eliminate, and factors regulating their succession and toxin production remain still to discover. A 4-year study revealed periodical mass development of diazotrophic Nostocales such as Dolichospermum spp. (previously Anabaena), Aphanizomenon gracile and expansive Cuspidothrix (previously Aphanizomenon) issatschenkoi in a lake affected by perennial blooms of Planktothrix agardhii (Oscillatoriales). Compared to Oscillatoriales, Nostocales reached the highest total biomass (up to $16 \mathrm{mg} \mathrm{L}^{-1}$ ) and contributed nearly 33$85 \%$ to the total biomass of filamentous cyanobacteria at higher water temperatures (average values 17.5$22.6^{\circ} \mathrm{C}$ ) and higher ratio (11.8-14.1) of dissolved inorganic nitrogen to dissolved inorganic phosphorus (DIN/ DIP). Species structure of Nostocales changed considerably from year to year as indicated by the Jaccard similarity index $(0.33-0.78)$. Concentrations of intracellular anatoxin-a (ANTX) ranged from 0.03 to $2.19 \mu \mathrm{g} \mathrm{L}^{-1}$ of the lake water, whilst extracellular toxin reached up to $0.55 \mu \mathrm{g} \mathrm{L}^{-1}$. The highest positive correlations were found between the intracellular ANTX and the biomass of Dolichospermum spp. $\left(R^{2}=0.73\right)$ and
\end{abstract}

\footnotetext{
M. Toporowska $(\bowtie) \cdot$ B. Pawlik-Skowrońska Department of Hydrobiology, University of Life Sciences in Lublin, Akademicka 13, 20-950 Lublin, Poland e-mail: magdalena.toporowska@up.lublin.pl

R. Kalinowska

Centre for Ecological Research, P.A.S., Experimental Station, Niecała 18, 20-080 Lublin, Poland
}

C. issatschenkoi $\left(R^{2}=0.43-0.65\right)$. Our study suggests that ANTX production by Dolichospermum depended mainly on water temperature, whereas that by C. issatschenkoi was related to water conductivity and DIN/DIP ratio. $\mathrm{P}_{-} \mathrm{PO}_{4}$ concentrations also seemed to be important. The relatively short-term mass development of neurotoxic Nostocales is an additional threat to shallow, highly eutrophic water bodies continuously affected by Oscillatoriales blooms and may be controlled mainly by the DIN/DIP ratio. ANTX should be considered as a pollutant of freshwaters.

Keywords Anatoxin-a DIN/DIP ratio - Anabaena Aphanizomenon issatschenkoi $\cdot$ Nutrients $\cdot$ Hypertrophic lake

\section{Introduction}

Water blooms caused by toxin-producing cyanobacteria are a serious problem not only in many eutrophic but also in mesotrophic and oligotrophic water bodies in the world (Henriksen et al. 1997; Lepistö et al. 2005; O’Neil et al. 2012; Kobos et al. 2013; Pearl 2014; Fernández et al. 2015). Numerous factors such as water temperature (preferred temperature $>15{ }^{\circ} \mathrm{C}$ ), light attenuation, vertical water mixing and turbidity, flushing rates, residence time, nutrient levels and ratios affect determination of cyanobacterial assemblage composition (i.e. $\mathrm{N}_{2-}$ fixing vs. non-fixing taxa) and biomass (Rapala et al. 1993; Dokulil and Teubner 2000; Pearl 2008; O’Neil et al. 2012). In spite of extensive studies and present 
knowledge on cyanobacteria ecology (Dokulil and Teubner 2000; Rapala et al. 1993; Pearl 2008; O’Neil et al. 2012; Molot et al. 2014; Fernández et al. 2015), prediction, prevention and successful elimination of cyanobacterial blooms are still difficult or sometimes even impossible (Molot et al. 2014; Cirés and Ballot 2016). Cyanobacterial blooms affect aquatic ecosystems. For example, they influence physicochemical features of water by increasing the $\mathrm{pH}$ and redox potential of water, decreasing light conditions and so on (Oliver and Ganf 2000). As a consequence, disappearance of submerged macrophytes and simplification of aquatic biocenoses occur (Scheffer 1998). Toxin production by bloom-forming cyanobacteria is an additional threat for living organisms including humans (Welker and Döhren 2006; Van Apeldoorn et al. 2007; Testai et al. 2016).

Recently, more attention has been paid to anatoxin-a (ANTX) produced by some species of freshwater cyanobacteria. This potent nicotinic agonist has caused animal fatalities around the world (Briand et al. 2003; Puschner et al. 2008). Potential ANTX producers including Dolichospermum, Aphanizomenon, Raphidiopsis, Cylindrospermum and others (Sivonen et al. 1990; Rapala et al. 1993; Bumke-Vogt et al. 1999; Ballot et al. 2010) may be easily overlooked due to their relatively short-term mass occurrence. As suggested by O'Neil et al. (2012), climate warming may support more frequent mass development and longer duration of blooms of ANTX producers, as well as expansion of invasive species (Cirés and Ballot 2016) such as Cylindrospermopsis raciborskii and Cuspidothrix issatschenkoi. ANTX is harmful to aquatic fauna (e.g. planktonic invertebrates, benthic insect larvae and ichthyofauna; Claska and Gilbert 1998; Oberemm et al. 1999; Toporowska et al. 2014) and plants (Mitrovic et al. 2004). Moreover, ANTX accumulation has been recently found in muscles of freshwater fish roach, Prussian carp, perch and bream being an ingredient in human diet in Europe (Pawlik-Skowrońska et al. 2013). Therefore, health and ecological risk caused by ANTX producers should be seriously considered.

We hypothesised that in a highly eutrophicated lake with heavy and perennial blooms of microcystinproducing Planktothrix agardhii, mass development of ANTX-producing cyanobacteria may also occur under specific water temperature and ratio of easy available forms of nutrients. ANTX production may depend on the same factors which regulate the development of particular Nostocales species.

\section{Materials and Methods}

\subsection{Study Area}

The study was carried out in a small (6 ha), shallow $(2.9 \mathrm{~m})$, flow-through and hypertrophic Lake Syczyńskie located in Eastern Poland $\left(51^{\circ} 17^{\prime} \mathrm{N}, 23^{\circ}\right.$ $14^{\prime} \mathrm{E}$; Ferencz et al. 2014). Agricultural catchment and lack of a sewage system in a village located near the lake were the main reasons of the high trophic status of the lake. Therefore, water blooms caused by filamentous cyanobacteria (Oscillatoriales), especially microcystinproducing P. agardhii (Pawlik-Skowrońska et al. 2008), have been observed there for many years. The study on the development and toxin production by $P$. agardhii were carried out at the same period as the investigations of Nostocales cyanobacteria, and the results were published previously (Toporowska and Pawlik-Skowrońska 2014).

\subsection{Field Methods}

Water samples for analyses of chemical parameters, phytoplankton (including cyanobacteria) abundance and biomass as well as cyanotoxin detection were taken from February or March to November from 2006 to 2009 , from the uppermost $(0-0.5 \mathrm{~m})$ water layer in the central part of the lake. The basic physical parameters of the lake water, including temperature, transparency (SD), $\mathrm{pH}$, conductivity and oxygen concentration, were measured in situ. Samples of cyanobacterial scum were also collected from the surface layer of the lake water in both 2006 and 2008.

\subsection{Laboratory Methods of Identification and Enumeration of Phytoplankton}

The taxonomic identification of phytoplankton (including cyanobacteria) was carried out by light microscopy. Nostocales identification and systematics were based mainly on Komárek (1996) and Wacklin et al. (2009), respectively. The quantitative structure of the algal community was analysed by means of an inverted microscope (Utermöhl 1958). For all Oscillatoriales and Nostocales with straight filaments, $100 \mu \mathrm{m}$ was set as 
one individual. One colony of Dolichospermum spp. and of coccoid cyanobacteria were recognised as individuals. Phytoplankton biomass was estimated by cell volume measuring (Hillebrand et al. 1999). The species similarities of Nostocales assemblages that occurred in the lake were compared using the Jaccard's index (Jaccard 1912). The index varies from 0 to 1 and was calculated from the following formula:

$S j=(a+b+c) / \mathrm{a}$

where

$a=$ number of species in sample A and sample B (joint occurrence),

$b=$ number of species in sample B but not in sample A,

$c$ number of species in sample A but not in sample B.

\subsection{Laboratory Analyses of Water Chemistry} and Anatoxin-a Concentration

$\mathrm{N}-\mathrm{NH}_{4}, \mathrm{~N}-\mathrm{NO}_{3}$ and $\mathrm{P}-\mathrm{PO}_{4}$ concentrations in the lake water were determined according to Hermanowicz et al. (1999), whereas chlorophyll-a concentration according to PN-ISO, 10260 (2002). The Trophic State Index based on water transparency ( $\mathrm{TSI}_{\mathrm{SD}}$ ) was calculated according to Carlson (1977). The mass ratio of dissolved inorganic nitrogen (DIN) to dissolved inorganic phosphorus (DIP) was calculated.

The extraction of ANTX from cyanobacterial biomass collected on filters GF/C (Whatman) was carried out in $75 \%(v / v)$ methanol (Merck, pure p.a.) acidified with $0.01 \mathrm{M} \mathrm{HCl}$, using ultrasonication (two times for $5 \mathrm{~min}, 50 \mathrm{~W}$; SONOPULS ultrasonic homogeniser, Bandelin). After centrifugation (14,000 rpm for $10 \mathrm{~min}$ at $17^{\circ} \mathrm{C}$ ) and collection of supernatants, filters with the biomass were back-extracted (once for $5 \mathrm{~min}$ ), and after centrifugation, the combined supernatants $(4.0-4.7 \mathrm{~mL})$ were collected in glass tubes and kept at $-20^{\circ} \mathrm{C}$ until the day of cyanotoxin analysis. The extraction of ANTX from the $1 \mathrm{~mL}$ scum of Dolichospermum lemmermannii, Dolichospermum flos-aquae and P. agardhii was carried out in $2 \mathrm{~mL}$ of $100 \%$ methanol acidified with $0.01 \mathrm{M}$ $\mathrm{HCl}$ using ultrasonication (three times for $5 \mathrm{~min}$ ). After centrifugation, supernatants were collected and kept at $-20{ }^{\circ} \mathrm{C}$. Filtered lake water was evaporated to dry. The residue was extracted in $75 \%$ methanol acidified with
$0.01 \mathrm{M} \mathrm{HCl}$. The fluorometric derivatisation of samples was performed as follows: a sample was mixed with 0.1 $\mathrm{Na}_{2} \mathrm{~B}_{4} \mathrm{O}_{7}$ and 4-fluoro-7-nitrobenzofurazan (NBD-F; Fluka) and incubated for $10 \mathrm{~min}$ in the dark at room temperature. The reaction was stopped with $1 \mathrm{M} \mathrm{HCl}$. Samples $(20 \mu \mathrm{L})$ were analysed by means of HPLC with fluorescence detection (Shimadzu; detector parameters ex $470 \mathrm{~nm}$, em $530 \mathrm{~nm}$ ) according to James et al. (1998). ANTX identification was carried out based on a standard retention time. The calibration curve for quantitative analysis was made with standard ANTX (Tocris, BioScience).

\subsection{Statistical Analyses}

An indirect multivariate method (DCA) was used to measure and illustrate gradients indicated by Nostocales community. Because the length of the gradient was between three and four standard deviations, redundancy analysis (RDA) was used to explore the relationships between the abundance of particular Nostocales species, $P$. agardhii and eight environmental variables (water temperature, conductivity, $\mathrm{pH}$, transparency, $\mathrm{N}-\mathrm{NO}_{3}$,

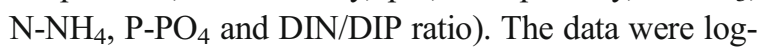
transformed to normalise them. A Monte Carlo analysis with 499 permutations was used to determine the most important variables. Variables which were significant $(P<0.05)$ and influenced cyanobacterial development were bolded. The ordination analyses were performed by means of CANOCO 4.5 software for Windows (ter Braak and Smilauer 2002). Correlation coefficient was also used to study relationships between the biomass of Nostocales and P. agardhii and physicochemical parameters of lake water, between particular cyanobacteria and between cyanobacteria biomass and concentrations of intracellular ANTX and ANTX and physicochemical parameters of the lake water.

\section{Results}

\subsection{Composition of Nostocales Community on the Background of Environmental Factors}

In the shallow, highly eutrophic (maximum $\mathrm{TSI}_{\mathrm{SD}}=83$ ), alkaline lake, the physicochemical conditions (Table 1) enhanced the periodical mass development of several species of filamentous cyanobacteria (Figs. 1 and 2 and Table 2) belonging to Nostocales species and strong 


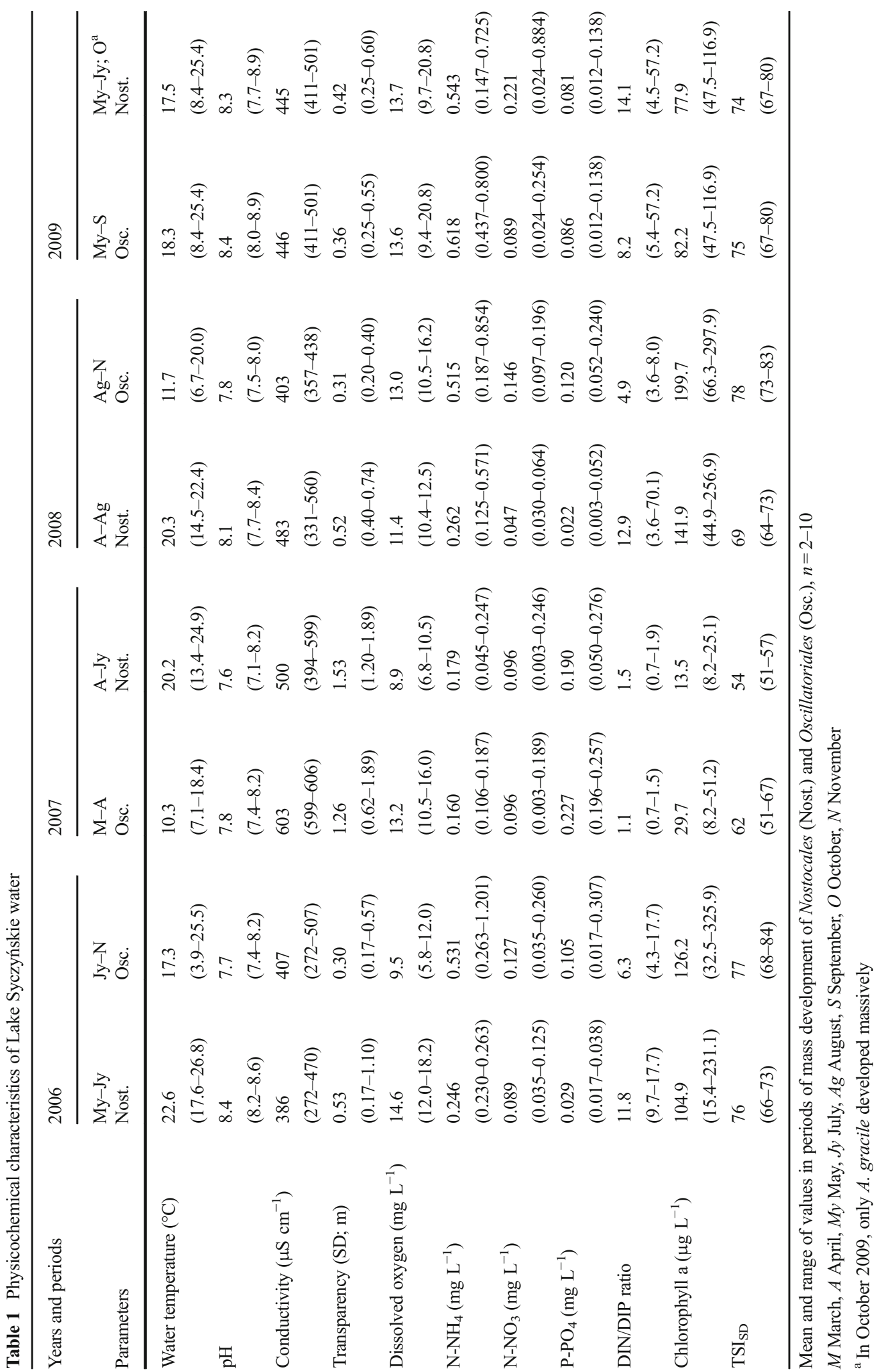



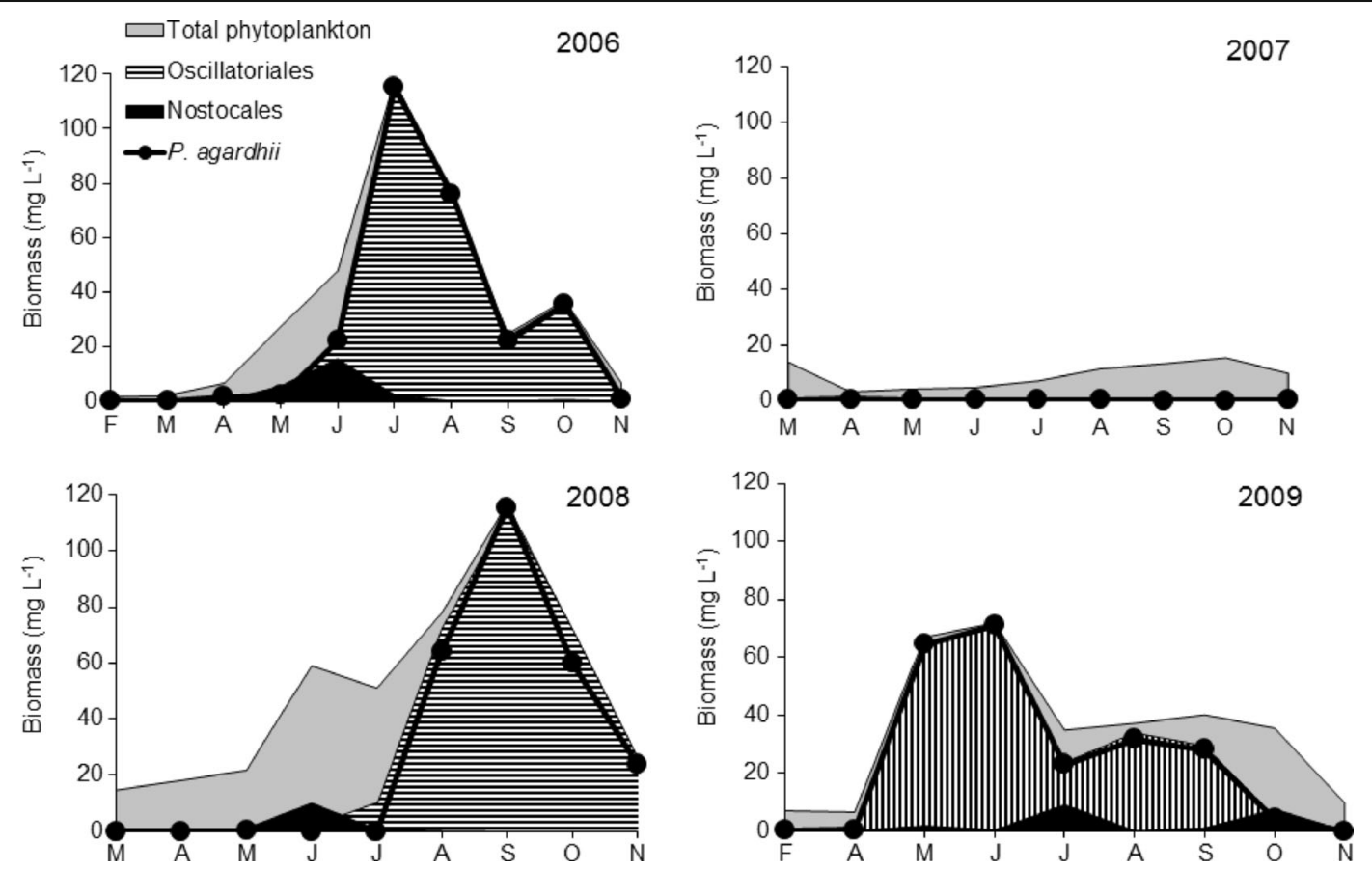

Fig. 1 Changes in biomass of Nostocales in comparison with the total biomass of phytoplankton and Oscillatoriales in Lake Syczyńskie in 2006-2009
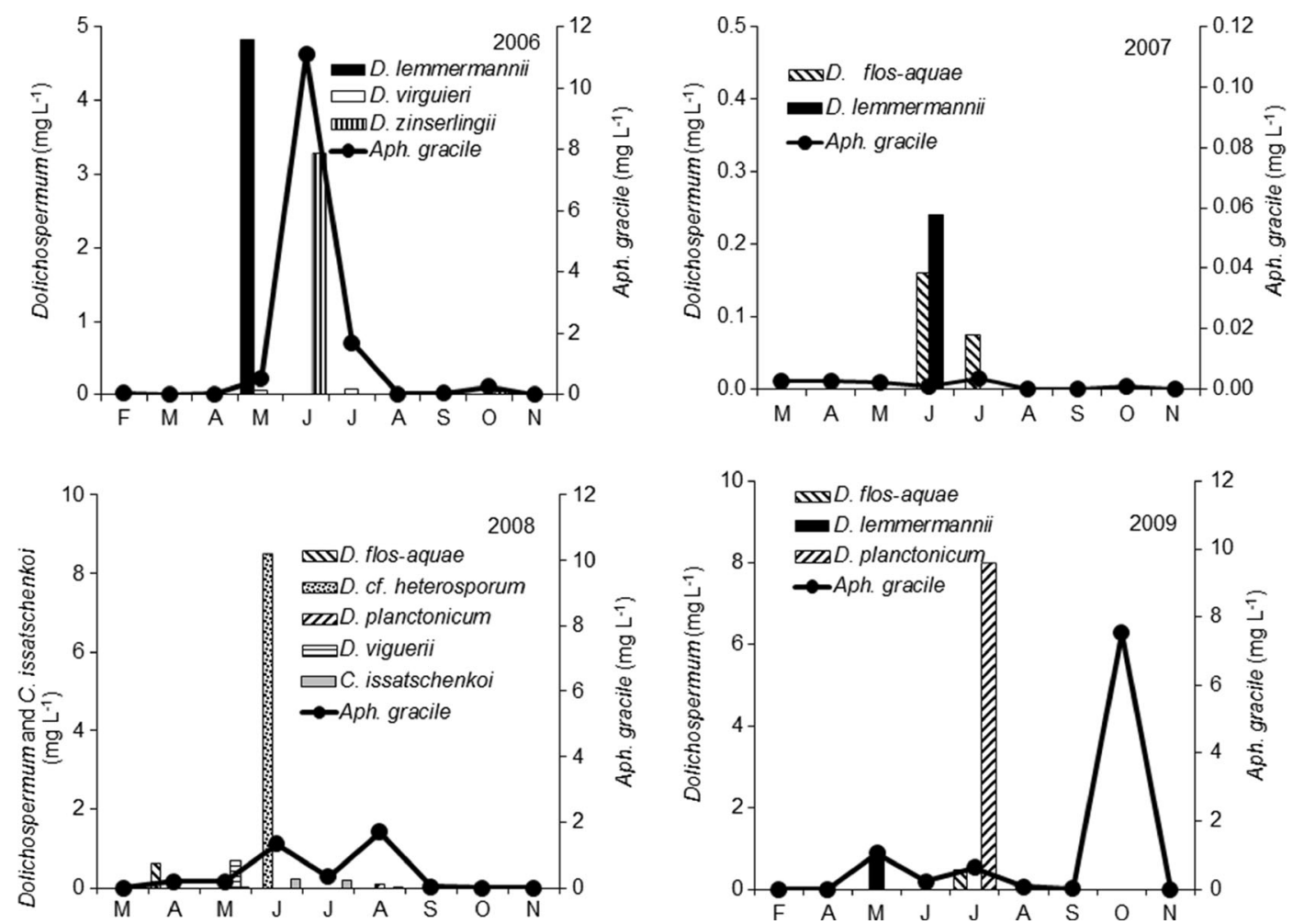

Fig. 2 The biomass of the most abundant species of Nostocales developed in Lake Syczyńskie in 2006-2009 
long-lasting water blooms of $P$. agardhii (Oscillatoriales). From 5 to 11 taxa of Nostocales, occurring in different proportions, were distinguished every year (Table 2). The most frequent species found were Aphanizomenon gracile, D. flos-aquae, D. lemmermannii, Dolichospermum viguieri, Dolichospermum planctonicum and C. issatschenkoi (Fig. 2 and Table 2). The highest species similarity of Nostocales, evaluated with the application of the Jaccard index, was found for the years 2006 and 2009 and the lowest for 2007 and 2008 (Table 3).

The concentrations of N-NH $4,-N-N_{3}$ and $\mathrm{P}_{4} \mathrm{PO}_{4}$ in Lake Syczyńskie water were generally very high throughout the study period (Table 1). The phytoplankton reached high total biomass with maximum values reaching from 13.73 to $117.30 \mathrm{mg} \mathrm{L}^{-1}$ (Fig. 1). It resulted in high-oxygen saturation of water and its very low transparency $0.17-0.20 \mathrm{~m}$ (Table 1 ). The contribution of cyanobacteria in the total biomass of phytoplankton varied considerably and ranged from 7.2 to $99.9 \%$ in 2006 , from 0.4 to $8.7 \%$ in 2007 , from 0.07 to $99.6 \%$ in 2008 and from 2.5 to $99.2 \%$ in 2009 . The total biomass of Nostocales reached up to $16 \mathrm{mg} \mathrm{L}^{-1}$, and their maximum contribution in the total biomass of cyanobacteria over the study period ranged from 33 to
$85 \%$ (Fig. 1). Periodically (Table 2 and Fig. 2), several Dolichospermum species achieved high density and biomass. Dolichospermum cf. heterosporum, $D$. planctonicum and A. gracile developed very intensively achieving maximum biomasses equal to $8.50,8.0$ and $11.11 \mathrm{mg} \mathrm{L}^{-1}$, respectively, whereas C. issatschenkoi reached a much lower biomass with a maximum value equal to $0.22 \mathrm{mg} \mathrm{L}^{-1}$ in 2008 (Fig. 2). These diazotrophic Nostocales developed in the lake together with Oscillatoriales predominated by $P$. agardhii, whose contribution in the total cyanobacterial biomass reached up to $99.2 \%$. However, the most intensive growth of Nostocales was observed before or after the maximum development of $P$. agardhii (Fig. 1) - mainly in spring/early summer seasons or in autumn and at seasonal mean water temperatures higher $\left(17.5-22.6{ }^{\circ} \mathrm{C}\right)$ than those supporting the development of Oscillatoriales $\left(10.3-18.3^{\circ} \mathrm{C}\right)$. The development of Nostocales was more intense than that of $P$. agardhii at higher ratio (11.8-14.1) of DIN/DIP (Table 1 and Fig. 3). In 2007, a strong decrease in the ratio of DIN/ DIP (1.1-1.5), which was due to the decrease in $\mathrm{N}-\mathrm{NH}_{4}$ and increase in $\mathrm{P}_{-} \mathrm{PO}_{4}$ concentrations, -essentially decreased both the species richness of Nostocales and the total abundance and biomass of cyanobacteria (Figs. 1

Table 2 Variability in abundance (range of values) of particular Nostocales taxa present in Lake Syczyńskie in the periods of ANTX occurrence in lake water (except 2007, when ANTX was not detected)

\begin{tabular}{|c|c|c|c|c|}
\hline \multirow[t]{2}{*}{ Taxa } & \multicolumn{4}{|c|}{ Abundance (ind. $10^{4} \mathrm{~L}^{-1}$ of water) } \\
\hline & $2006(\mathrm{My}-\mathrm{Ag})$ & $2007(\mathrm{M}-\mathrm{O})$ & $2008(\mathrm{~A}-\mathrm{Ag})$ & 2009 (My-Jy) \\
\hline Aphanizomenon gracile & $0.029-959.4$ & $0-0.3$ & $28.7-116.0$ & $20.0-92.2$ \\
\hline Cuspidothrix issatschenkoi ${ }^{\mathrm{a}}$ & $0-6.1$ & - & $0-30.7$ & $0-3.1$ \\
\hline Dolichospermum cf. heterosporum & - & - & $0-883.6$ & - \\
\hline D. compactum & $0-0.2$ & - & $0-51.4$ & $0-001$ \\
\hline D. crassum & - & - & - & $0-0.3$ \\
\hline D. flos-aquae $\mathrm{a}^{\mathrm{a}}$ & $0-0.3$ & $0-6.0$ & $0-23.5$ & $0-11.0$ \\
\hline D. heterosporum & - & - & $0-0.001$ & - \\
\hline D. lemmermannii ${ }^{\mathrm{a}}$ & $0-181.1$ & $0-9.0$ & $0-0.1$ & $0-15.0$ \\
\hline D. mendotae & - & - & $0-0.001$ & - \\
\hline D. planctonicum & - & - & $0-0.8$ & $0-105.7$ \\
\hline D. viguieri & $0-18.9$ & $0-0.2$ & $0-16.6$ & $0-0.09$ \\
\hline D. zinserlingii & $0-250.4$ & - & $0-12.4$ & - \\
\hline Dolichospermum sp. & $0-0.6$ & $0-0.2$ & - & $0-0.2$ \\
\hline Number of taxa & 8 & 5 & 11 & 9 \\
\hline
\end{tabular}

$M$ March, A April, My May, Jy July, Ag August, $O$ October; - taxon not found

${ }^{\mathrm{a}}$ Main ANTX producers 
Table 3 Jaccard index of similarity of Nostocales assemblages in Lake Syczyńskie in 2006-2009

\begin{tabular}{llll}
\hline Year & 2007 & 2008 & 2009 \\
\hline 2006 & 0.63 & 0.58 & 0.78 \\
2007 & - & 0.33 & 0.63 \\
2008 & - & - & 0.58 \\
\hline
\end{tabular}

and 2 and Table 2). During that time, the Nostocales biomass was found to be approximately 20 -fold and the P. agardhii biomass almost 800 -fold lower compared to other years; therefore, the values of $\mathrm{TSI}_{\mathrm{SD}}$ index decreased from 77 in 2006 to 54 in 2007 but later increased again (Table 1).

The relationships between the abundance of particular Nostocales species, P. agardhii and environmental variables were also analysed by using RDA analysis (Fig. 3). Monte Carlo permutation test $(P<0.05)$ showed that the most significant factors were water temperature $(\lambda=0.12$; $F=4.94 ; P=0.002)$ and water transparency $(\lambda=0.07$; $F=2.97 ; P=0.004)$. The analysis confirmed that the higher water temperatures were more important for the development of Nostocales than that of P. agardhii. Water transparency was a consequence of phytoplankton (mostly $P$. agardhii; Table 4) blooms, and this parameter showed much lower values $(0.17-1.10 \mathrm{~m})$ in 2006 , 2008 and 2009 compared to 2007 (Table 1), when cyanobacterial biomass was low. Transparency was much lower during blooms of $P$. agardhii than during mass development of Nostocales. Statistical analysis suggests

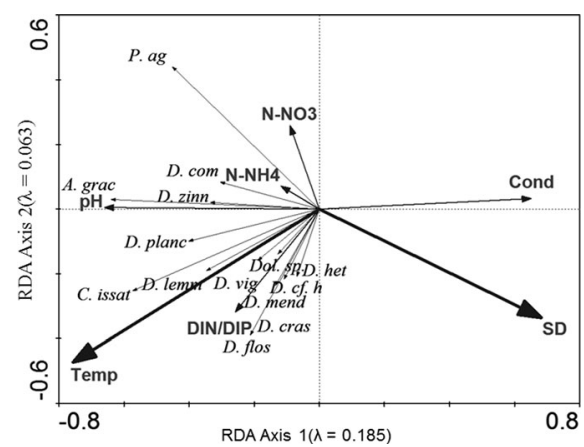

Fig. 3 Redundancy analysis (RDA) biplots for Nostocales, $P$. agardhii and environmental parameters. The bolded arrows indicate the significant variables which had influence on development of cyanobacteria and were based on Monte Carlo permutation test $(P<0.05)$. Temp temperature, $S D$ transparency, Cond conductivity, $\mathrm{N}-\mathrm{NH}_{4}$ ammonium nitrogen, $\mathrm{N}-\mathrm{NO}_{3}$ nitrate nitrogen, $D I N / D I P$ the mass DIN/DIP ratio, A. grac A. gracile, $C$. issat $C$. issatschenkoi, D. flos D. flos-aquae, D. lemm D. lemmermannii, $D$. het $D$. heterosporum, $D$. cf. h D. cf. heterosporum, D. planc D. planctonicum, D. vig D. viguieri, D. com D. compactum, Dol. sp. Dolichospermum sp. and P. ag P. agardhii that this physical factor had no influence on the development of most Dolichospermum species but negatively correlated with the growth of $A$. gracile, D. compactum, $D$. planctonicum and $D$. zinserlinglii. Interestingly, RDA analysis (Fig. 3) revealed that the DIN/DIP ratio supported the development of most Dolichospermum species and $C$. issatschenkoi, and it was of higher importance $(\lambda=0.04 ; F=1.76 ; P=0.072)$ than the concentrations of particular nutrients such as $\mathrm{N}^{-N_{4}}(\lambda=0.03 ; F=1.22$; $P=0.316), \mathrm{N}^{-N}(\lambda=0.02 ; F=0.97 ; P=0.316)$ and $\mathrm{P}-$ $\mathrm{PO}_{4}$. Similar results were obtained by the calculation of correlation coefficient (Table 4). However, we observed that water temperature was more important for the growth of Dolichospermum spp., whereas the DIN/DIP ratio was found to be more important for the development of C. issatschenkoi. Statistical analyses (Fig. 3 and Table 4) confirmed that species belonging to Dolichospermum genera and C. issatschenkoi reached the highest biomasses during the same periods and at similar environmental conditions. Correlation between their biomasses was equal to 0.49 . A gracile growth was favoured in different seasons.

\subsection{Anatoxin-a Production in the Lake}

ANTX concentrations in the lake varied considerably within the study years, seasons and months (Fig. 4); however, toxin was detected only during mass development of Nostocales (Figs. 1 and 2), and it was not found in the scum of $P$. agardhii. In 2006, the highest concentration of intracellular ANTX in the lake water was equal to $1.82 \mu \mathrm{g} \mathrm{L}^{-1}$ and was observed during D. lemmermannii bloom (Fig. 4). Moreover, as much as $3457 \mu \mathrm{g}$ of ANTX was detected in $1 \mathrm{~L}$ of the very dense surface scum created by this species. In 2008 (Fig. 4), from 1.66 to $2.19 \mu \mathrm{g} \mathrm{L}^{-1}$ of intracellular ANTX was found from May to July during the mass development of several Dolichospermum species and C. issatschenkoi. During that year in spring, $228 \mathrm{\mu g} \mathrm{L}^{-1}$ of intracellular ANTX was also found in the scum created by D. flos-aquae. In 2009, concentrations of intracellular ANTX reached from 0.21 to $0.92 \mu \mathrm{g} \mathrm{L}^{-1}$, during which time D. lemmermannii, $D$. planctonicum and D. flos-aquae were found abundant in the lake except $C$. issatschenkoi. Extracellular ANTX was detected at concentrations from 0.41 to $0.55 \mu \mathrm{g} \mathrm{L}^{-1}$ only in 2008 , during which period Dolichospermum spp. and C. issatschenkoi proliferated. Statistical analyses showed that concentrations 
Table 4 Correlations between biomass of cyanobacteria and physicochemical parameters of lake water, between particular cyanobacteria, cyanobacteria biomass and concentration of intracellular ANTX and intracellular ANTX and physicochemical parameters of lake waters

\begin{tabular}{|c|c|c|c|c|c|}
\hline & P. agardhii & Dolich. spp. & A. gracile & C. issatsch. & ANTX \\
\hline Water temperature & 0.18 & $0.42 *$ & 0.19 & 0.28 & $0.34^{*}$ \\
\hline $\mathrm{pH}$ & 0.22 & 0.22 & 0.23 & 0.15 & 0.29 \\
\hline Conductivity & $-0.52 *$ & -0.30 & -0.27 & $-0.38 *$ & $-0.39 *$ \\
\hline Transparency (SD) & $-0.60^{*}$ & -0.16 & -0.22 & -0.19 & -0.26 \\
\hline $\mathrm{N}-\mathrm{NH}_{4}$ & 0.20 & -0.02 & -0.14 & 0.01 & -0.10 \\
\hline $\mathrm{N}-\mathrm{NO}_{3}$ & -0.09 & -0.20 & 0.31 & -0.13 & -0.14 \\
\hline $\mathrm{P}-\mathrm{PO}_{4}$ & -0.11 & -0.14 & -0.18 & -0.24 & $-0.34^{*}$ \\
\hline DIN/DIP ratio & -0.05 & 0.29 & 0.02 & $0.61 *$ & $0.39^{*}$ \\
\hline P. agardhii & - & -0.08 & 0.06 & -0.12 & 0.07 \\
\hline Dolichospermum spp. & - & - & 0.17 & $0.49^{*}$ & $0.37^{*}$ \\
\hline A. gracile & - & - & - & 0.07 & -0.06 \\
\hline C. issatschenkoi & - & - & - & - & $0.64 *$ \\
\hline
\end{tabular}

Dolich. spp. Dolichospermum spp., C. issatsch. C. issatschenkoi

* Statistically significant values $(P<0.05)$

of intracellular ANTX positively correlated with the biomass of Dolichospermum spp. and
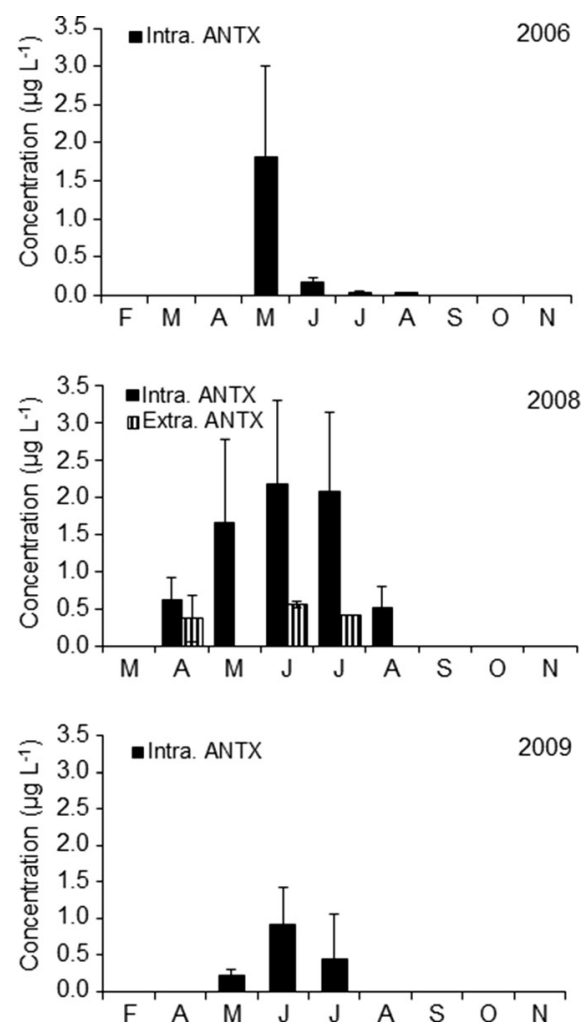

Fig. 4 Concentrations of intracellular (intra.) and extracellular (extra.) fraction of anatoxin-a in the water of Lake Syczyńskie in 2006-2009 (mean \pm SD)
C. issatschenkoi (Table 4). More detailed analysis (Fig. 5) showed that in 2006, intracellular ANTX positively correlated $\left(R^{2}=0.73\right)$ with the biomass of all Dolichospermum species (Fig. 5), whereas in 2008 and 2009, correlation of cell-bound ANTX with C. issatschenkoi biomass $\left(R^{2}=0.65\right.$ and 0.43 , respectively) was found. However, Dolichospemum spp. could also produce ANTX, particularly in 2008 (Fig. 5). No correlation between $A$. gracile biomass and ANTX was found.

It seems that the production of intracellular ANTX was related to the same factors which controlled the development of particular Nostocales cyanobacteria (Table 4). ANTX production by Dolichospermum spp. was related mainly to water temperature, whereas that by $C$. issatschenkoi to the increasing DIN/DIP ratio and decreasing water conductivity. However, decreasing $\mathrm{P}-\mathrm{PO}_{4}$ concentrations seemed to be also important. In general, amongst all years, intracellular ANTX was found to be most intensively produced during summer periods, at which time maximum development of particular Nostocales was observed and $P$. agardhii was found to be abundantly high or increasing. Intracellular ANTX reached up to $40.6 \mu \mathrm{g} \mathrm{mg}^{-1}$ of the biomass of Dolichospermum spp. in $2006,9.7 \mathrm{\mu g} \mathrm{mg}^{-1}$ of the biomass of Dolichospermum spp. and C. issatschenkoi in 2008 and $64.3 \mu \mathrm{g} \mathrm{mg}^{-1}$ of the $C$. issatschenkoi biomass in 2009 (Fig. 6). 
Fig. 5 Relationships between the biomass $\left(\mathrm{mg} \mathrm{L}^{-1}\right)$ of particular species of Nostocales and intracellular anatoxin-a concentrations $\left(\mu \mathrm{g} \mathrm{L}^{-1}\right)$ in water of Lake Syczyńskie
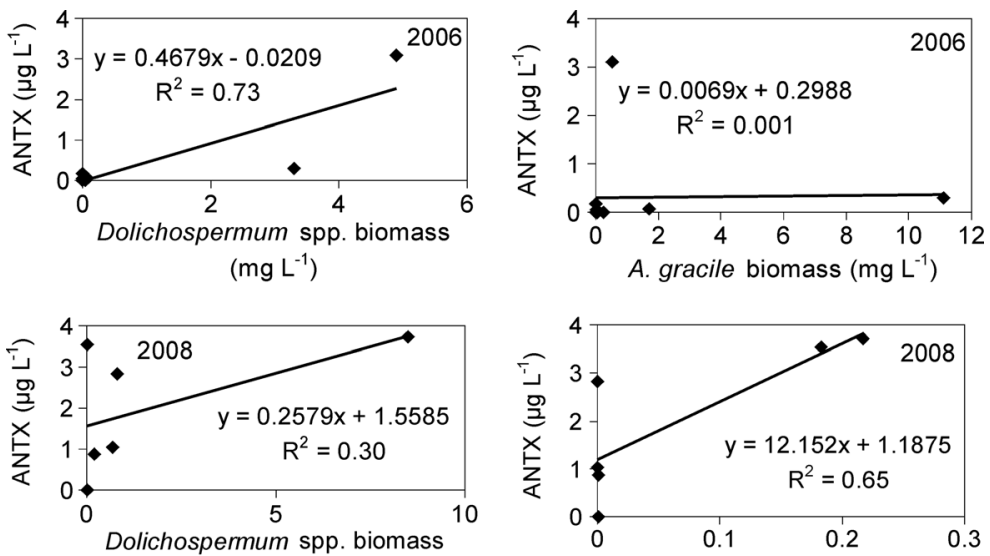

$\left(\mathrm{mg} \mathrm{L}^{-1}\right)$
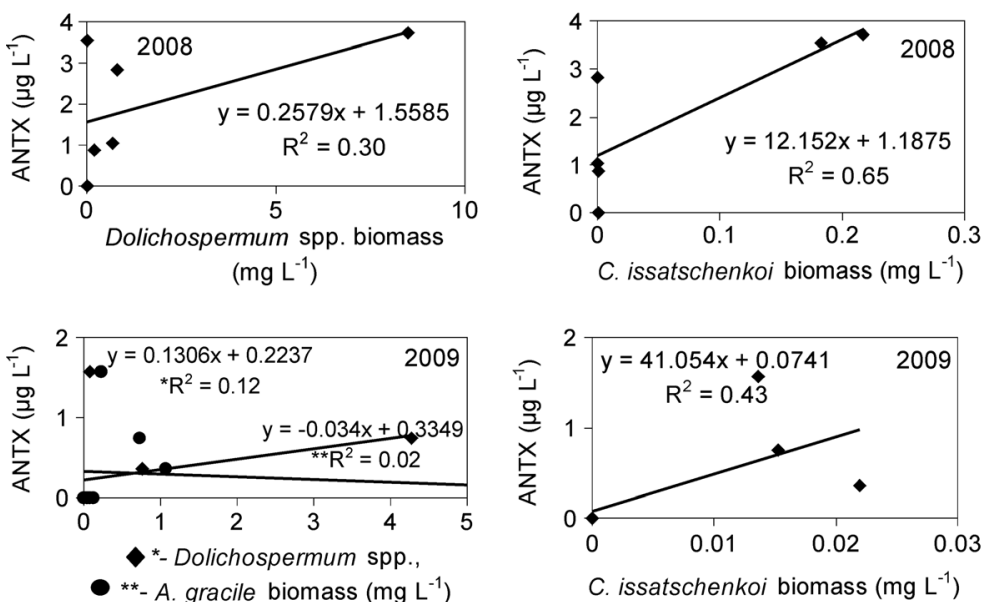

\section{Discussion}

Ecology of cyanobacteria and cyanobacterial blooms and their causes and effects attract more and more attention for mass development of neurotoxin producers (Sivonen et al. 1990; Henriksen et al. 1997; BumkeVogt et al. 1999; Pawlik-Skowrońska et al. 2004; Pawlik-Skowrońska et al. 2013; Heath et al. 2016; Cirés and Ballot 2016). This 4-year study carried out in the shallow hypertrophic lake dominated by $P$. agardhii

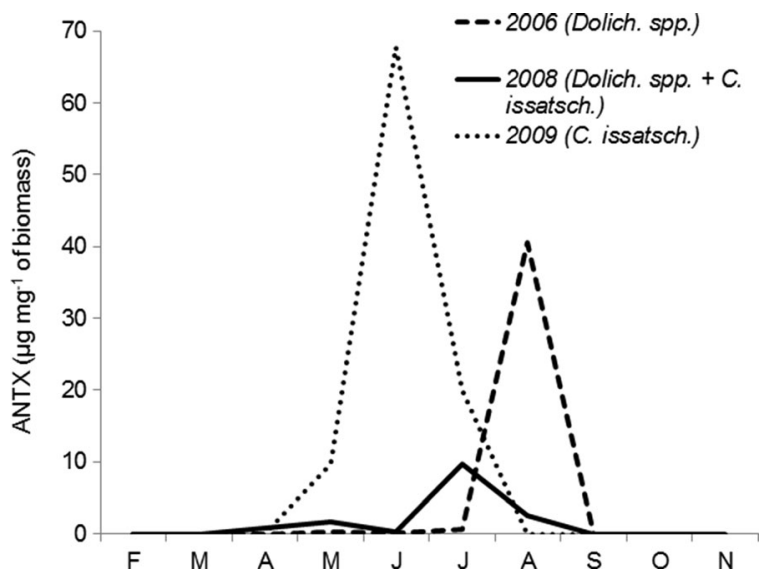

Fig. 6 Concentrations of intracellular ANTX per biomass of potential ANTX producers in particular years (Dolich. Dolichospermum species, C. issatsch. C. issatschenkoi)
(Pawlik-Skowrońska et al. 2008; Toporowska et al. 2014) showed a high variability both in qualitative and quantitative structure of assemblages of ANTXproducing Nostocales. Nostocales developed massively in spring and at early summer seasons at higher water temperatures compared to Oscillatoriales. The temperatures were similar to the optimum temperatures (20$25^{\circ} \mathrm{C}$ ) reported by Rapala et al. (1993) and were higher than those characteristic for Oscillatoriales (Dokulil and Teubner 2000). However, Nostocales proliferated also in other seasons at temperatures from 13.2 to $28.8^{\circ} \mathrm{C}$ (Bumke-Vogt et al. 1999; Pawlik-Skowrońska et al. 2004). Therefore, other factors such as fluctuations in concentration and/or proportions of nutrients seem to be more important for the growth of Nostocales. Majority of reports (Rapala et al. 1993; Catherine et al. 2008; Altman and Pearl 2012), however, showed the effect of individual nutrient compounds. In the lake studied, the DIN/DIP ratio, not concentrations of particular dissolved nutrients, was next to the temperature and water transparency, which was related to $P$. agardhii biomass, the most important factor that modulated the proliferation of Nostocales cyanobacteria. At a very low DIN/ DIP ratio of 0.7-1.9, a decrease in the abundance and biomass of both Nostocales and Oscillatoriales resulted in the elimination of cyanobacterial blooms, despite optimal water temperatures and high-nutrient 
concentrations in the lake water. This suggests that besides increasing the total N/P ratio over 20, providing eukaryotic algae as competitors over cyanobacteria (Pearl 2008), decreasing DIN/DIP ratio to a very low level (ca. 1/1) may also be one of the methods of controlling cyanobacterial blooms. A long-term study carried out in Zemborzycki Reservoir showed that cyanobacteria biomass decreased with decreasing P$\mathrm{PO}_{4}$ concentrations and with increasing DIN/DIP ratio (above 23) (Pawlik-Skowrońska et al. 2013). A decrease in Nostocales biomass with increasing biomass of $P$. agardhii, decreasing water transparency and increasing shading was typical for both Lake Syczyńskie and Zemborzycki Reservoir. The decrease in light had a strong role in the decline of Dolichospermum circinalis bloom in hypertrophic reservoir in Argentina (Fernández et al. 2015). No data exist on the potential toxic effect of $P$. agardhii on ANTX producers. But, recent experiment by $\mathrm{Ma}$ et al. (2015) showed that different species of Microcystis inhibited the development of $A$. flos-aquae to various degrees; however, pure microcystin-LR did not inhibit $A$. flos-aquae development. This suggests some possible allelopathic interactions between cyanobacteria, but further studies in this field are required.

Mass development of Nostocales was observed in other shallow and eutrophic lakes in Europe (BumkeVogt et al. 1999; Pawlik-Skowrońska et al. 2004; Ballot et al. 2010) or South America (Becker et al. 2004; Ruiz et al. 2013), and other factors controlling Nostocales growth and structure were revealed. For example, in a shallow subtropical Brazilian lake, in which the abundance of $D$. circinalis and $D$. spiroides reached up to $4.5 \times 10^{6}$ ind. $\mathrm{L}^{-1}$ (Becker et al. 2004), the maximum bloom was preceded by an event of strong turbulence in the lake system. This resulted in the availability of nutrients and dispersion of the cyanobacteria akinetes, stored in the sediment, into the water column. Later blooms were supported by progressive reduction in wind velocity and longer stabilisation period in the water column. Recently, Molot et al. (2014) suggested that anoxia may play a critical role in bloom formation and the consequent release of ferrous iron from the sediments. In Lake Syczyńskie, anoxic conditions occurred in winter/spring period in 2006 (Toporowska et al. 2010), which could favour later cyanobacterial blooms. Vegetation period in 2007 was free of blooms and was preceded by warm winter preventing anoxia. Simultaneously, an increase in supply dynamics, such as runoff, hypodermic and underground supply, favoured water mixing, as well as a negative balance of total phosphorous, soluble reactive phosphorous and ammonium (Dawidek et al. 2009). As a consequence, changes in nutrient concentrations and ratios in the lake water were observed. Therefore, in the studied lake, complex lake-catchment processes probably play a key role in the formation of cyanobacterial blooms. These processes may be very dynamic (Dawidek et al. 2009; Ferencz et al. 2014) and shape most physicochemical parameters of the lake water, regulating the growth of particular cyanobacterial species.

In Lake Syczyńskie, the development of Aphanizomenon species was more stable and long lasting than species belonging to Dolichospermum genera. Moreover, A. gracile reached a high biomass also in cold periods, even under the ice cover, at a water temperature $\leq 4{ }^{\circ} \mathrm{C}$ (Toporowska et al. 2010). Occurrence of Aphanizomenon in temperate lakes seems to be more frequent than that of Cuspidothrix (Ballot et al. 2010; Kobos et al. 2013). For example, Ballot et al. (2010), amongst 61 Aphanizomenon strains found in a German lake in years 20072008, classified 59 as A. gracile and only 2 as C. issatschenkoi. One of them was a very effective ANTX producer $\left(2.35 \mathrm{mg} \mathrm{g}^{-1} \mathrm{FW}\right)$. It seems that C. issatschenkoi, D. flos-aquae and D. lemmermannii were the main ANTX producers in Lake Syczyńskie. The maximal production of ANTX reaching up to $67.7 \mu \mathrm{g} \mathrm{mg}^{-1} \mathrm{FW}$ of cyanobacterial biomass was much higher compared to other water bodies. For example, A. flos-aquae and Dolichospermum spp. from Portuguese freshwaters produced more than $20 \mu \mathrm{g}$ of ANTX per gram of dry weight (Osswald et al. 2009). Production of ANTX is strain specific, but our field study showed that it may change with changing abiotic factors, which also influence the cyanobacterial growth. This is in agreement with the experiments by Rapala et al. (1993) and Osswald et al. (2009). Our results suggest that water temperature, DIN/DIP ratio, conductivity and $\mathrm{P}_{-} \mathrm{PO}_{4}$ concentrations had the most significant effect on ANTX production. According to Rapala et al. (1993), the optimal temperature for ANTX production was between 19.8 and $22{ }^{\circ} \mathrm{C}$. But, decrease in toxin levels at higher temperatures seemed to depend on the species since the growth of both toxic Anabaena (now Dolichospermum) cultures suffered, whereas Aphanizomenon grew best at $30{ }^{\circ} \mathrm{C}$. Also, high intensity of light limited ANTX 
production in Dolichospermum but not in Aphanizomenon. Light limitation caused by an increased in the abundance of $P$. agardhii might intensify ANTX production in Lake Syczyńskie. Lowest concentrations of ANTX in Nostocales biomass found in periods of their most intensive mass development may also support the growth-differentiation balance hypothesis (Herms and Mattson 1992), suggesting that actively dividing and expanding cells are less likely to produce secondary metabolites. We did not find correlations between ANTX production and ammonium and nitrate nitrogen, which is contrast to the findings of Rapala et al. (1993), who showed that particularly $\mathrm{N}_{2}$ or $\mathrm{N}-\mathrm{NH}_{4}$ limitation caused an increase in ANTX production. The significant negative correlation observed between ANTX and $\mathrm{P}-\mathrm{PO}_{4}$ concentrations is in opposition to the findings of Rapala et al. (1993) and in agreement with recent experiment carried out on benthic Phormidium sp. by Heath et al. (2016). The experiment suggested that ANTX may be produced as a stress response to growth-limiting conditions because toxin concentrations were found to be the lowest under high-nitrogen and high-phosphorus treatment supporting the above-mentioned growthdifferentiation balance hypothesis.

The capability of some Nostocales to producing ANTX as well as several different cyanotoxins and other metabolites of still unknown biological activity (Welker and Döhren 2006) increases their threat to aquatic ecosystems. For example, D. lemmermannii was confirmed as a producer of neurotoxic anatoxin-a(s), saxitoxins and hepatotoxic microcystins (MCs) (Sivonen et al. 1990; Henriksen et al. 1997; Lepistö et al. 2005), D. flos-aquae as a producer of microcystins (Sivonen et al. 1992), which were found also in the scum of D. flos-aquae from Lake Syczyńskie (data not published), whereas invasive $C$. issatschenkoi (Kastovsky et al. 2010) as a producer of paralytic shellfish poison (PSP) (Li et al. 2003). A. gracile was previously identified as a PSP and cylindrospermopsin producer (Rücker et al. 2007; Kokociński et al. 2013). ANTX production by this species has not been proved neither by our field study nor by previous laboratory and field investigations (Cirés and Ballot 2016). Due to toxin production, even a short-term mass appearance of different Nostocales species seems to be a real hazard for freshwater ecosystems and their users. Risk to human health associated with the environmental occurrence of anatoxins was reviewed recently by Testai et al. (2016).
Summing up, in a shallow and highly eutrophicated water body, mass development of Nostocales, potential ANTX producers, may depend on water temperature, but it seems to be controlled mainly by DIN/DIP ratio. In contrast to the long-lasting $P$. agardhii blooms, the periodical predominance of particular Nostocales genus, especially belonging to Dolichospermum genus, may change very quickly. It seems that ANTX production is controlled by more complex factors than the development of particular Nostocales species. The impact of development of MC-producing P. agardhii cannot be excluded, and experimental studies on Nostocales-Oscillatoriales interactions are strongly required. Evaluating the impact of varying factors on Nostocales community dynamics and ANTX production in eutrophic water bodies seems to be a key to develop strategies to avoid blooms of toxigenic cyanobacteria. There is a strong need of further field and experimental studies. We suggest that due to the global warming and increasing problem of toxigenic cyanobacterial blooms, neurotoxic ANTX should be considered as a pollutant of freshwaters, which needs to be monitored.

Acknowledgments The study was supported by the Polish Ministry of Science and Higher Education, project no. 304396636 (granted to B.P.S.). Thanks are expressed to E. Słowikowska MSc for her technical assistance. The authors would like to also acknowledge the European Cooperation in Science and Technology, COST Action ES 1105 "Cyanobacterial blooms and toxins in water resources: occurrence, impacts and management (CYANOCOST)", for adding value to this study through networking and knowledge sharing with European experts and researchers in the field.

\section{Compliance with Ethical Standards}

Conflict of Interest The authors declare that they have no conflict of interest.

Open Access This article is distributed under the terms of the Creative Commons Attribution 4.0 International License (http:// creativecommons.org/licenses/by/4.0/), which permits unrestricted use, distribution, and reproduction in any medium, provided you give appropriate credit to the original author(s) and the source, provide a link to the Creative Commons license, and indicate if changes were made.

\section{References}

Altman, J. C., \& Pearl, H. W. (2012). Composition of inorganic and organic nutrient sources influences phytoplankton community structure in the New River Estuary, North Carolina. Aquatic Ecology, 46, 269-282. 
Ballot, A., Fastner, J., Lentz, M., \& Wiedner, C. (2010). First report of anatoxin-a-producing cyanobacterium Aphanizomenon issatschenkoi in northeastern Germany. Toxicon, 56(6), 964-971.

Becker, V., de Cardoso, L. S., \& da Motta Marques, D. (2004). Development of Anabaena Bory ex Bornet \& Flahault (Cyanobacteria) blooms in a shallow, subtropical lake in southern Brazil. Acta Limnologica Brasiliensia, 16(4), 306-317.

Briand, J. F., Jacquet, S., Bernard, C., \& Humbert, J. F. (2003). Health hazards for terrestrial vertebrates from toxic cyanobacteria in surface water ecosystems. Veterinary Research, 34, 361-377.

Bumke-Vogt, C., Mailahn, W., \& Chorus, I. (1999). Anatoxin-a and neurotoxic Cyanobacteria in German lakes and reservoirs. Environmental Toxicology, 14, 117-125.

Carlson, R. E. (1977). A trophic state index for lakes. Limnology and Oceanography, 22(2), 361-369.

Catherine, A., Quiblier, C., Yéprémian, C., Got, P., Groleau, A., Vinçon-Leite, B., Bernard, C., \& Troussellier, M. (2008). Collapse of a Planktothrix agardhii perennial bloom and microcystin dynamics in response to reduced phosphate concentrations in a temperate lake. FEMS Microbiology Ecology, 65(1), 61-73.

Cirés, S., \& Ballot, A. (2016). A review of the phylogeny, ecology and toxin production of bloom-forming Aphanizomenon spp. and related species within the Nostocales (cyanobacteria). Harmful Algae, 54, 21-43.

Claska, M. E., \& Gilbert, J. J. (1998). The effect of temperature on the response of Daphnia to toxic cyanobacteria. Freshwater Biology, 39, 221-232.

Dawidek, J., Pęczuła, W., \& Ferencz, B. (2009). The role of catchment and in-lake processes in shaping trophic conditions of the shallow Lake Syczyńskie (Eastern Poland). Ecohydrology \& Hydrobiology, 9(2), 193-200.

Dokulil, M. T., \& Teubner, K. (2000). Cyanobacterial dominance in lakes. Hydrobiologia, 438, 1-12.

Ferencz, B., Dawidek, J., \& Toporowska, M. (2014). Hydrochemical versus biological conditions of the functioning of three shallow lakes in Łęczna-Włodawa. Water Environment Research, 86(3), 269-276.

Fernández, C., Estrada, V., \& Parodi, E. R. (2015). Factors triggering cyanobacteria dominance and succession during blooms in a hypereutrophic drinking water supply reservoir. Water, Air, \& Soil Pollution, 226(3), 113.

Heath, M., Wood, S. A., Young, R. G., \& Ryan, K. G. (2016). The role of nitrogen and phosphorus in regulating Phormidium sp. (Cyanobacteria) growth and anatoxin production. FEMS Microbiology Ecology, 92(3), fiw021.

Henriksen, P., Carmichael, W. W., An, J., \& Moestrup, Ø. (1997). Detection of an anatoxin-a(s)-like anticholinesterase in natural blooms and cultures of cyanobacteria/blue-green algae from Danish lakes and in the stomach contents of poisoned birds. Toxicon, 35(6), 901-913.

Hermanowicz, W., Dożańska, W., Dojlido, J., \& Koziorowski, B. (1999). Fizyczno-chemiczne badanie wody i ścieków. Warszawa: Arkady.

Herms, D. A., \& Mattson, W. J. (1992). The dilemma of plants: to grow or defend. Quarterly Review of Biology, 67, 283-335.
Hillebrand, H., Dürselen, C. D., Kirschtel, D., Pollingher, U., \& Zohary, T. (1999). Biovolume calculation for pelagic and benthic microalgae. Journal of Phycology, 35, 403-424.

Jaccard, P. (1912). The distribution of the flora in the alpine zone. New Phytologist, 11(2), 37-50.

James, K. J. A., Fukey, I. R., Scherlock, M. A., Stack, M., Twohing, R. B., Caudwell, O., \& Skulberg, M. (1998). Sensitive determination of anatoxin-a, homoanatoxin-a and their degradation products by liquid chromatography with fluorometric detection. Journal of Chromatography A, 798, 147-157.

Kastovsky, J., Hauer, T., Mares, J., Krautova, M., Besta, T., Komárek, J., et al. (2010). A review of the alien and expansive species of freshwater cyanobacteria and algae in the Czech Republic. Biological Invasions, 12, 3599-3625.

Kobos, J., Błaszczyk, A., Hohlfeld, N., Toruńska-Sitarz, A., Krakowiak, A., Hebel, A., et al. (2013). Cyanobacteria and cyanotoxins in Polish freshwater bodies. Oceanological and Hydrobiological Studies, 42(4), 358-378.

Kokociński, M., Mankiewicz-Boczek, J., Jurczak, T., Spoof, L., Meriluoto, J., Rejmonczyk, E., et al. (2013). Aphanizomenon gracile (Nostocales), a cylindrospermopsin-producing cyanobacterium in Polish lakes. Environmental Science and Pollution Research, 20(8), 5243-5264.

Komárek, J. (1996). Klič k určováni vodnich květú sinic v České Republice. In B. Maršálek, V. Varšner, \& P. Marvan (Eds.), Vodni květy sinic (pp. 22-85). Brno: Nadatio Flos-aquae.

Lepistö, L., Rapala, J., Lyra, C. C., Berg, K., Erkomaa, K., \& Aissakainen, J. (2005). Occurrence and toxicity of cyanobacterial blooms dominated by Anabaena lemmermannii P. Richter and Aphanizomenon spp. in boreal lakes in 2003. Algological Studies, 117, 315-328.

Li, R., Carmichael, W. W., \& Pereira, P. (2003). Morphological and 16S rRNA gene evidence for reclassification of the paralytic shellfish toxin producing Aphanizomenon flosaquae LMECYA 31 as Aphanizomenon issatschenkoi (Cyanophyceae). Journal of Applied Phycology, 39, 814 818.

Ma, H., Wu, Y., Gan, N., Zheng, L., Li, T., \& Song, L. (2015). Growth inhibitory effect of Microcystis on Aphanizomenon flos-aquae isolated from cyanobacteria bloom in Lake Dianchi, China. Harmful Algae, 42, 43-51.

Mitrovic, S. M., Pflugmacher, S., James, K. J., \& Furey, A. (2004). Anatoxin-a elicits an increase in peroxidase and glutathione S-transferase activity in aquatic plants. Aquatic Toxicology, 68(2), 185-192.

Molot, L. A., Watson, S. B., Creed, I. F., Trick, C. G., McCabe, S. K., Verschoor, M. J., et al. (2014). A novel model for cyanobacteria bloom formation: the critical role of anoxia and ferrous iron. Freshwater Biology, 59(6), 1323-1340.

O’Neil, J. M., Davis, T. W., Burford, M. A., \& Gobler, C. J. (2012). The rise of harmful cyanobacteria blooms: the potential roles of eutrophication and climate change. Harmful Algae, 14, 313-334.

Oberemm, A., Becker, J., Codd, G. A., \& Steinberg, C. (1999). Effects of cyanobacterial toxins and aqueous crude extracts of cyanobacteria on the development of fish and amphibians. Environmental Toxicology, 14, 77-88.

Oliver, R. L., \& Ganf, G. G. (2000). Freshwater blooms. In B. A. Whitton \& M. Potts (Eds.), The ecology of Cyanobacteria (pp. 149-194). Dordrecht: Kluwer Academic Publishers. 
Osswald, J., Rellán, S., Gago-Martinez, A., \& Vasconcelos, V. (2009). Production of anatoxin-a by cyanobacterial strains isolated from Portuguese fresh water systems. Ecotoxicology, 18(8), 1110-1115.

Pawlik-Skowrońska, B., Skowroński, T., Pirszel, J., \& Adamczyk, A. (2004). Relationship between cyanobacterial bloom and anatoxin-a and microcystin occurrence in the eutrophic dam reservoir (SE Poland). Polish Journal of Ecology, 52(4), 379-490.

Pawlik-Skowrońska, B., Pirszel, J., \& Kornijów, R. (2008). Spatial and temporal variation in microcystin concentrations during perennial bloom of Planktothrix agardhii in a hypertrophic lake. Annales de Limnologie-International Journal of Limnology, 44(2), 63-68.

Pawlik-Skowrońska, B., Kalinowska, R., \& Skowroński, T. (2013). Cyanotoxin diversity and food web bioaccumulation in a reservoir with decreasing phosphorus concentrations and perennial cyanobacterial blooms. Harmful Algae, 28, 118-125.

Pearl, H. W. (2008). Nutrient and other environmental controls of harmful cyanobacterial blooms along the freshwater-marine continuum. In H. H. Kenneth (Ed), Cyanobacterial Harmful Algal Blooms: State of the Science and Research Needs. Advances in Experimental Medicine and Biology, 619, 217-237.

Pearl, H. W. (2014). Mitigating harmful cyanobacterial blooms in a human- and climatically-impacted world. Life, 4, 988-1012.

PN-ISO, 10260. (2002). Water quality. Measurement of biochemical parameters. Spectrophotometric determination of chlorophyll-a. Warsaw: PWN.

Puschner, B., Hoff, B., \& Tor, E. R. (2008). Diagnosis of anatoxina poisoning in dogs from North America. Journal of Veterinary Diagnostic Investigation, 20, 89-92.

Rapala, J., Sivonen, K., Luukkainen, R., \& Niemela, S. (1993). Anatoxin-a concentration in Anabaena and Aphanizomenon under different environmental conditions and comparison of growth by toxic and non-toxic Anabaena strains laboratory study. Journal of Applied Phycology, 5, 581-591.

Rücker, J., Stüken, A., Nixdorf, B., Fastner, J., Chorus, I., \& Wiedner, C. (2007). Concentrations of particulate and dissolved cylindrospermopsin in 21 Aphanizomenon-dominated temperate lakes. Toxicon, 50(6), 800-809.

Ruiz, M., Galanti, L., Ruibal, A. L., Rodriguez, M. I., Wunderlin, D. A., \& Amé, M. V. (2013). First report of microcystins and anatoxin-a co-occurrence in San Roque Reservoir (Córdoba, Argentina). Water, Air, \& Soil Pollution, 224(6), 1-17.
Scheffer, M. (1998). Ecology of shallow lakes. London: Chapman and Hall.

Sivonen, K., Niemelä, S. I., Niemi, R. M., Lepistö, L., Luoma, T. H., \& Räsänen, L. A. (1990). Toxic cyanobacteria (bluegreen algae) in Finnish fresh and coastal waters. Hydrobiologia, 190(3), 267-275.

Sivonen, K., Skulberg, O. M., Namikoshi, M., Evans, W. R., Carmichael, W. W., \& Rinehart, K. L. (1992). Two methyl ester derivatives of microcystins, cyclic heptapeptide hepatotoxins, isolated from Anabaena flos-aquae strain CYA 83/1. Toxicon, 30(11), 1465-1471.

ter Braak, C. J. F., \& Smilauer, P. (2002). CANOCO reference manual and user's guide to Canoco for Windows: software for canonical community ordination (version 4.5). Ithaca: Microcomputer Power.

Testai, E., Buratti, F. M., Funari, E., Manganelli, M., Vichi, S., Arnich, N., et al. (2016). Review and analysis of occurrence, exposure and toxicity of cyanobacteria toxins in food. EFSA Supporting Publications, 13(2).

Toporowska, M., \& Pawlik-Skowrońska, B. (2014). Four-year study on phytoplankton biodiversity in a small hypertrophic lake affected by water blooms of toxigenic cyanobacteria. Polish Journal of Environmental Studies, 23(2), 491-499.

Toporowska, M., Pawlik-Skowrońska, B., Krupa, D., \& Kornijów, R. (2010). Winter versus summer blooming of phytoplankton in a shallow lake: effect of hypertrophic conditions. Polish Journal of Ecology, 58(1), 159-168.

Toporowska, M., Pawlik-Skowrońska, B., \& Kalinowska, R. (2014). Accumulation and effects of cyanobacterial microcystins and anatoxin-a on benthic larvae of Chironomus spp. (Diptera: Chironomidae). European Journal of Entomology, 111(1), 83-90.

Utermöhl, H. (1958). Zur vervollkommung der quantitativen methodik. Mitteilungen der Internationale Vereinigung für Teoretische und Angewandte Limnologie, 9, 1-38.

Van Apeldoorn, M. E., Van Egmond, H. P., Speijers, G. J. A., \& Bakker, G. J. I. (2007). Toxins of cyanobacteria. Review. Molecular Nutrition \& Food Research, 51, 760.

Wacklin, P., Hoffmann, L., \& Komárek, J. (2009). Nomenclatural validation of the genetically revised cyanobacterial genus Dolichospermum (Ralfs ex Bornet et Flahault) comb. nova. Fottea, 9(1), 59-64.

Welker, M., \& Döhren, H. (2006). Cyanobacterial peptides-nature's own combinatorial biosynthesis. FEMS Microbiology Reviews, $30,530-563$. 